\title{
Glaciological response to distal tephra fallout from the 1947 eruption of Hekla, south Iceland
}

\author{
Martin P. KIRKBRIDE, ${ }^{1}$ Andrew J. DUGMORE ${ }^{2}$ \\ ${ }^{1}$ Department of Geography, University of Dundee, Dundee DD1 4HN, Scotland \\ E-mail:m.p.kirkbride@dundee.ac.uk \\ ${ }^{2}$ S.E.E.G.S., University of Edinburgh, Drummond Street, Edinburgh EH8 9XP, Scotland
}

\begin{abstract}
Glacier responses to tephra deposition are shown to be highly variable where wind-transported eruption plumes produce narrow distal fallout zones with steep lateral thickness gradients. Significant but short-lived advances of faster-flowing glaciers can be triggered by deposition from modest eruptions. The 1947 eruption of Hekla, south Iceland, covered nearby glaciers with variable thicknesses of tephra, causing dramatic spatial variations in ablation rate. Relative snow ablation increased by an estimated $>80 \%$ at the eastern margin of Eyjafjallajökull, but decreased by $>54 \%$ at the western margin. Relative ice ablation increased by only $4 \%$ in the east but decreased by $>75 \%$ at the western margin, only $15 \mathrm{~km}$ distant. The effect on mass balance therefore depends on tephra distribution as well as on the nature of the glacier surface. On Gígjökull, retardation of ablation was greatest at the terminus, associated with an anomalous advance of $\geq 328 \mathrm{~m}$ between 1947 and 1954. Other glaciers in the fallout zone show either no recognizable response, or accelerated retreat. Advances will be short-lived due to the rapid redistribution of supraglacial tephra in a maritime climate, and the potential for discriminating between volcanically and climatically forced advances in the glacio-geomorphological record is low. The long-term glaciological effect of volcanism is to create thin, low-albedo covers after reworking, which make conditions less favourable for glaciation.
\end{abstract}

\section{INTRODUGTION}

Though the direct impacts of volcanic eruptions on glaciers are well documented (Brugman and Meier, 1981; Pierson and others, 1990; Thouret, 1990), the effects of distal fallout remain poorly researched. Direct or proximal impacts include largescale blasting of ice and beheading of glaciers, catastrophic melting beneath flows of hot ash and mud, and preservation of glacier remnants beneath deposits of thick volcanogenic sediment (Brugman and Meier, 1981; Sturm and others, 1986; Major and Newhall, 1989; Pierson and others, 1990; Thouret, 1990; Trabant and Meyer, 1992; Branney and Gilbert, 1995). Distal impacts are less direct but occur over a much wider area within the depositional zone of airfall tephra. Where tephra cover is less than a few centimetres thick, absorption of shortwave radiation and ablation are increased. Under thicker covers, the low thermal conductivity of pumaceous material provides insulation for the underlying ice. The short-term thermal effect of both natural and artificial darkening of snow and ice surfaces is well known (Bozhinskiy and others, 1986; Adhikary and others, 1997, 2000; Kayastha and others, 2000; Konovalov, 2000), but the existence and characteristics of volcanically triggered glacier fluctuations are poorly researched, especially in the glacio-geomorphological record.

This paper presents evidence for a volcanically induced advance of Gígjökull, a northern outlet of the Eyjafjallajökull ice cap, south Iceland (Fig. 1), and contrastingly accelerated retreat of other parts of the same ice cap. Published data (Thórarinsson, 1954) on the fallout from the 1947 eruption of the Hekla volcano (hereafter termed H1947) is com- bined with the 1930-95 record of glacier length variations (Sigurðsson, 1998) to relate the distribution of tephra thickness to glacier response. The half-century which has elapsed since the H1947 eruption allows comparison of glacier fluctuations before and after the event, over a time-scale appropriate for assessing the duration of the glaciological response.

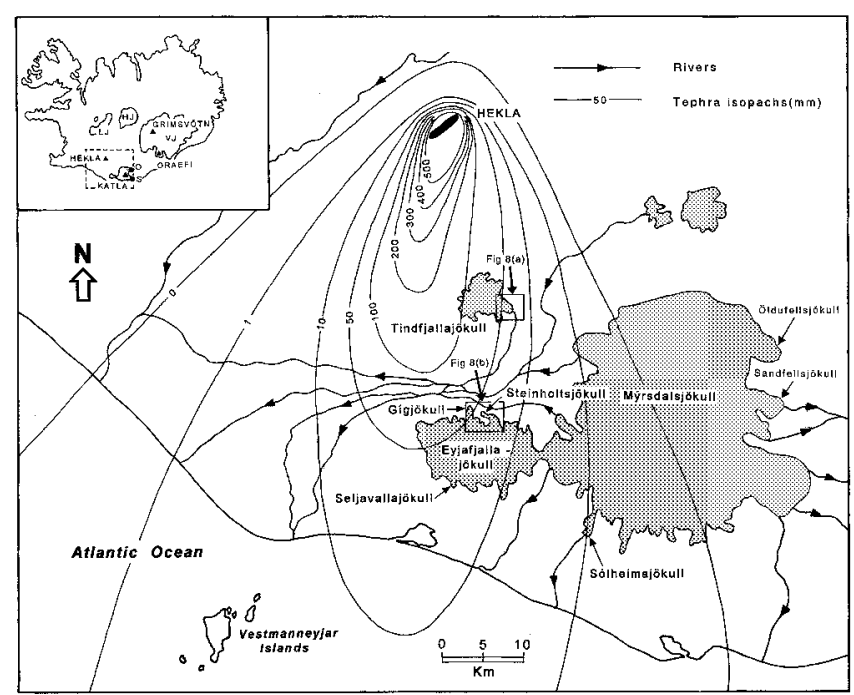

Fig. 1. Isopach map of tephra thickness (in $\mathrm{mm}$ ) deposited by the 1947 Hekla eruption (from Thórarinsson, 1954). Inset: location of sites mentioned in the text. HF, Hofsjökull; LF, Langjökull; VJ, Vatnajökull; O, Öldufellsjökull; S, Sandfellsjökull. 
Table 1. Summary of reported critical and effective supraglacial debris thicknesses for ablation of snow and ice

\begin{tabular}{|c|c|c|c|c|}
\hline Location & $\begin{array}{l}\text { Critical thickness } \\
\qquad \mathrm{mm}\end{array}$ & $\begin{array}{l}\text { Effective thickness } \\
\text { mm }\end{array}$ & Surface condition & Source \\
\hline Gígjökull, Iceland & 5.5 & 2 & tephra/ice & University of Edinburgh, unpublished data \\
\hline Breiðamerkurjökull, Iceland & $4-7$ & - & tephra/ice & Lister (1953) \\
\hline South Cascade Glacier, Washington, U.S.A. & 24 & 3 & tephra/snow & Driedger (1981) \\
\hline Isfallsglaciaren, Sweden & - & 9 & rock/ice & Østrem (1964) \\
\hline Kaskawulsh Glacier, Canada & - & 15 & rock/ice & Loomis $(1970)$ \\
\hline Glacier de Tsidjiore Neuve, Switzerland & $\sim 30$ & 10 & rock/ice & Small and Clark (1974) \\
\hline Various (central Asia) & 15 & 7 & rock/ice & Konovalov (2000) \\
\hline Theoretical & - & $20-30$ & rock/ice & Bozhinskiy and others (1986) \\
\hline Barpu Glacier, Pakistan & - & $\sim 10$ & rock/ice & Khan (1989) \\
\hline Rakhiot Glacier, Pakistan & $\sim 30$ & $\sim 10$ & rock/ice & Mattson and Gardner (1991) \\
\hline Burroughs Glacier, Alaska, U.S.A. & $<20$ & $\sim 7$ & rock/ice & Syverson and Mickelson (1995) \\
\hline Lirung Glacier, Nepal & 1.33 & 0.25 & rock/ice & Adhikary and others (2000) \\
\hline Khumbu Glacier, Nepal & 15 & 5 & rock/snow & Fujii (1977) \\
\hline Various (central Asia) & 20 & 7 & rock/snow & Konovalov (2000) \\
\hline
\end{tabular}

Results are discussed in terms of the possible impact of volcanism on the glacio-geomorphological record.

\section{THE 1947 ERUPTION OF HEKLA}

Hekla is one of the most active volcanoes in Iceland, having erupted at least 22 times since the Norse colonization in the ninth century AD. The eruption of 29 March 1947 followed a dormant period of 101 years, and was the first since the commencement of systematic glacier monitoring in the region. The event was well documented by eyewitnesses and postevent research (eg. Thórarinsson, 1950, 1954) and was notable in the southward trajectory of the tephra plume, taking the eruption cloud over the ice caps Tindfjallajökull, western Mýrdalsjökull and Eyjafjallajökull (Fig. 1). Most of the $215 \times$ $10^{6} \mathrm{~m}^{3}$ of tephra was erupted during the early explosive phase of the eruption and fell onto a stable, extensive spring snowpack. The fallout pattern shown in Figure 1 is a composite of an early phase of dark andesitic tephra followed, after 0.5 hour, by a later phase of light dacitic tephra (Thórarinsson, 1954). The andesitic plume travelled on an axis to the south-southwest, the dacitic plume almost due south. Tephra on Tindfjallajökull and Eyjafjallajökull included both phases, whereas western Mýrdalsjökull received only dacitic tephra. Contemporaneous thickness measurements have been interpolated (Fig. 1) to show a simple elongate elliptical fallout pattern with the downwind axis passing west of Tindfjallajökull and crossing the western margin of Eyjafjallajökull. The area of land covered by direct airfall was $3130 \mathrm{~km}^{2}$. Further afield, deposition occurred on ships in the North Atlantic before the plume turned east and the most distal traces of fallout were eluviated from the atmosphere by frontal rainfall over Finland (Salmi, 1948; Thórarinsson, 1954).

\section{EFFECT OF THE TEPHRA FALL ON ABLATION}

In common with other types of debris cover, there is a critical thickness of supraglacial tephra which separates accelerated melting under a thin cover from retarded melting under a thick cover. The difference is due to the changing balance between enhanced absorption of shortwave radiation by the low-albedo tephra, and low conductive heat flow through a material whose thermal conductivity is probably $<0.5 \mathrm{~W} \mathrm{~m}^{-1}$
$\mathrm{K}^{-1}$ (by comparison with the published value for pumice in Clark, 1966). Though several curves relating debris thickness to ablation rate exist for silicic rock debris (e.g. Lundstrom and others, 1993; Humlum, 1996; Kirkbride and Warren, 1999), few comparable data exist for volcanogenic debris, and the selection of a curve appropriate to this study requires care.

Following Adhikary and others (1997), two important tephra thicknesses are identified:

(1) The critical thickness is the thickness at which sub-debris ablation rate equals clean-ice or -snow ablation rate.

(2) The effective thickness represents the debris thickness beneath which ablation is maximized.

Data for each are summarized in Table 1. Values differ for snow and ice substrates. Melting of snow is more rapid than

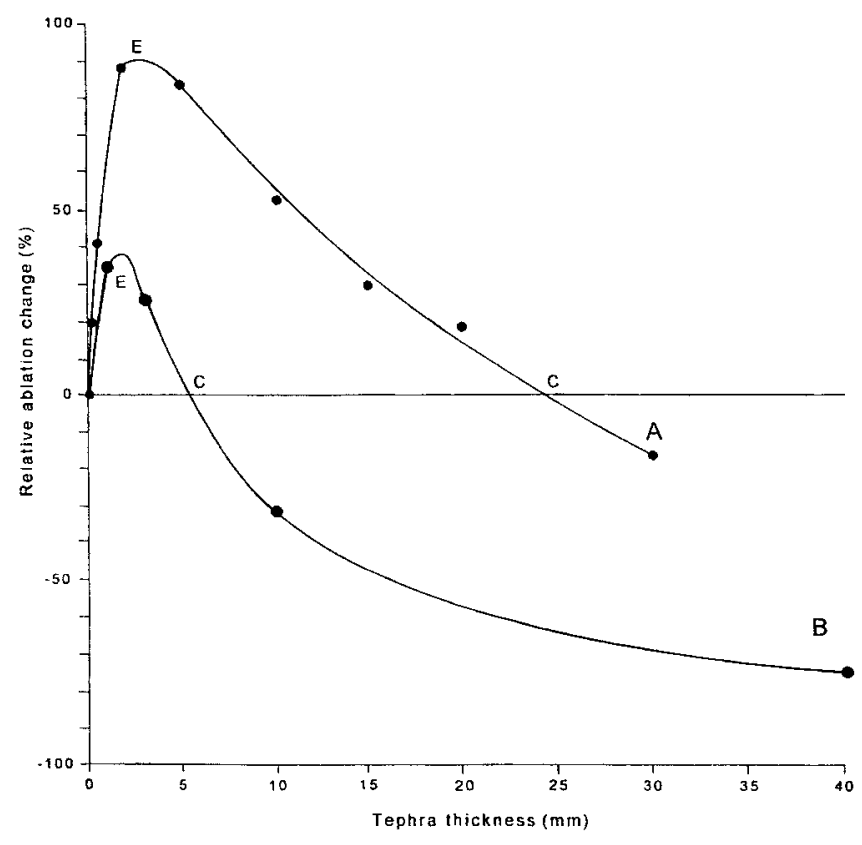

Fig. 2. Relationships between tephra cover thickness and relative ablation change. Curve $A$ applies to tephra on firn (Driedger, 1981), curve B to tephra on ice (unpublished data from the Gigjökull ablation zone). E and $C$ indicate effective and critical thicknesses of tephra. 


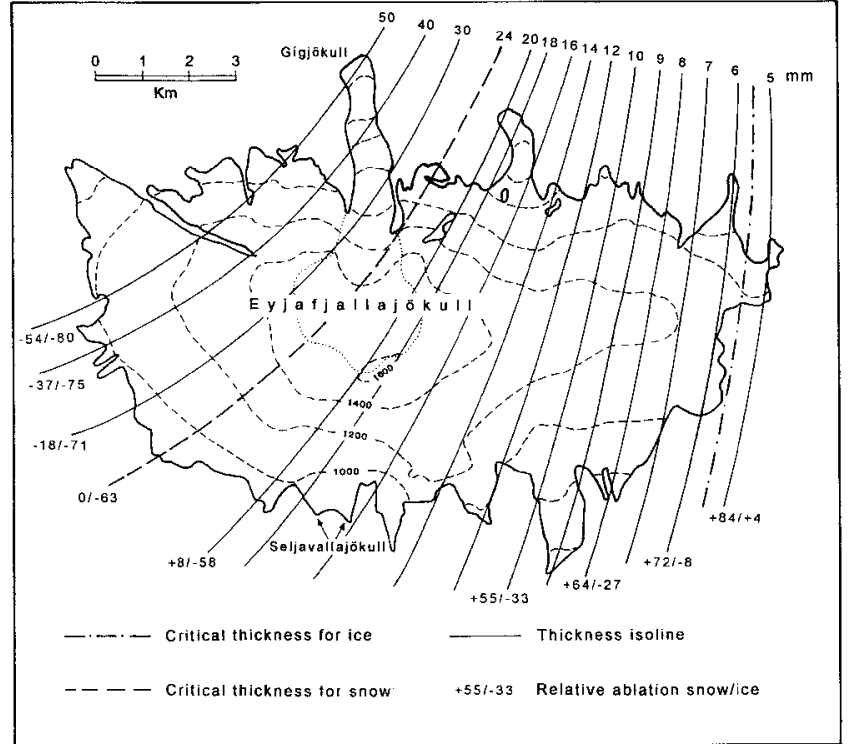

Fig. 3. Interpolated H1947 isopachs for the Eyjafjallajökull ice cap and western Mýrdalsjökull, showing the effect on melting using the thickness-ablation relationships for ice and snow from Figure 2.

melting of ice for a given cover thickness, so different thickness/ablation relationships must be applied to glacier surfaces above and below the seasonal snowline.

\section{Ablation of firn}

Driedger's (1981) relationship (curve A in Fig. 2) is based on stake measurements from artificial plots of the 1980 Mount St Helens tephra on a firn-covered surface at South Cascade Glacier, Washington, U.S.A., and is adopted in this study as the best available data. Ablation is expressed as relative ablation, i.e. the percentage ratio between the uncovered firn and sub-tephra rates where positive and negative values represent increased and decreased ablation respectively. Driedger (1981) locates the effective thickness as $3 \mathrm{~mm}$ of tephra (at least $88 \%$ ablation increase), and the critical thickness as $24 \mathrm{~mm}$ relative to "clean" firn, but $20 \mathrm{~mm}$ relative to "natural" (slightly dirty) firn.

\section{Ablation of glacier ice}

For glacier ice surfaces, curve B (Fig. 2) has been constructed from unpublished data, using similar methods to Driedger's (1981). Artificial plots of H1947 tephra were maintained on the lower tongue of Gígjökull for periods of up to 10 days, and results are again expressed as relative ablation. Effective and critical thicknesses are 2 and $5.5 \mathrm{~mm}$ respectively, consistent with the empirical observations of Lister (1953). In contrast, the effective thickness for granitic rock debris is $10-30 \mathrm{~mm}$ because of the higher thermal conductivity (Table 1).

\section{Post-eruption ablation on Eyjafjallajökull}

Relative ablation immediately after the H1947 airfall has been mapped for Eyjafjallajökull by interpolating additional isopachs between the coarse classes used in the original isopach map (Fig. 3). Interpolation is possible given the smooth change in deposit thickness with distance from the eruptive source. This is probable given fallout from an initial
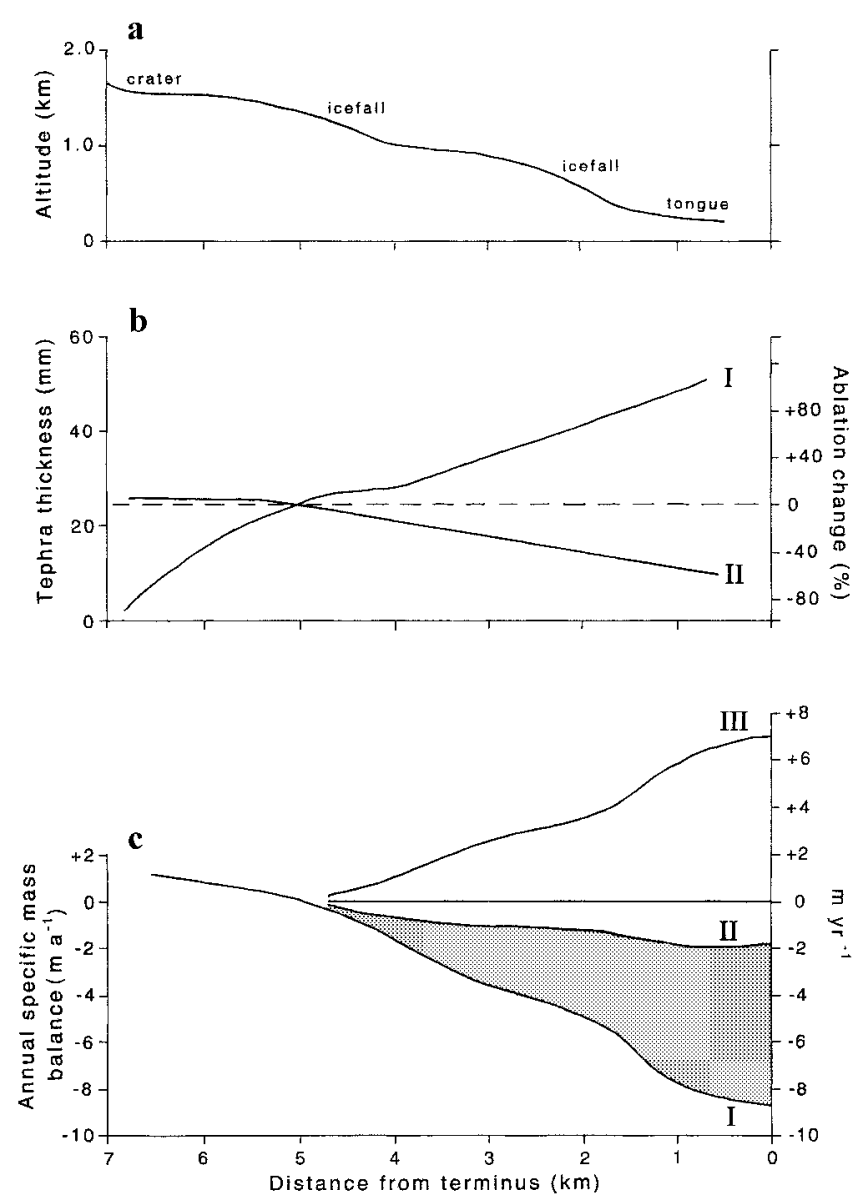

Fig. 4. (a) Topographic profile of Gígjökull. (b) Distribution of H1947 tephra thickness on the long profile (I) and its effect on ablation rate (II). (c) Inferred bare-ice ablation gradient (I), using data from 1936-38 from Hoffelsjökull, south Iceland (Ahlmann and Thórarinsson, 1938), and modified ablation gradient (II) beneath the tephra cover. Curve III is the difference between the bare-ice and covered-ice ablation gradients (positive values indicate greater insulation of underlying ice).

plume base at the tropopause, or an altitude of about $10 \mathrm{~km}$ (Thórarinsson, 1954). Class widths of $1 \mathrm{~mm}$ are used up to $10 \mathrm{~mm}$ thickness, $2 \mathrm{~mm}$ up to $20 \mathrm{~mm}$ thickness, and $10 \mathrm{~mm}$ for thicker tephra. Critical thickness lines for snow and ice are plotted from Figure 2 at 5.5 and $24 \mathrm{~mm}$. The latter encloses $703 \mathrm{~km}^{2}(22 \%)$ of the terrestrial fallout zone. Each isopach is labelled with relative ablation values pertaining to snow and ice surfaces, though tephra was initially deposited onto spring snow over most of the area in Figure 1.

The results show that tephra cover exceeded the critical thickness for snow over about one-third of the ice cap. The effective thickness line passed across the western margin of Mýrdalsjökull where snow ablation rates would have almost doubled. Over Eyjafjallajökull, maximum calculated enhancement of $\sim 85 \%$ occurred in the east and decreased steadily westwards then northwestwards as the orientation of the isolines changes. The critical thickness line separates the two main outlet glaciers to the north. Steinsholtsjökull lay in the zone of accelerated ablation $(\sim 10-22 \mathrm{~mm}$ tephra thickness; calculated ablation increased by $\sim 10-55 \%$ ). Though the upper accumulation zone of Gígjökull was bisected by the critical thickness line, ablation would have been reduced over most of the glacier.

There are no published observations of the seasonal change in snow cover for 1947. However, as snowmelt allowed 


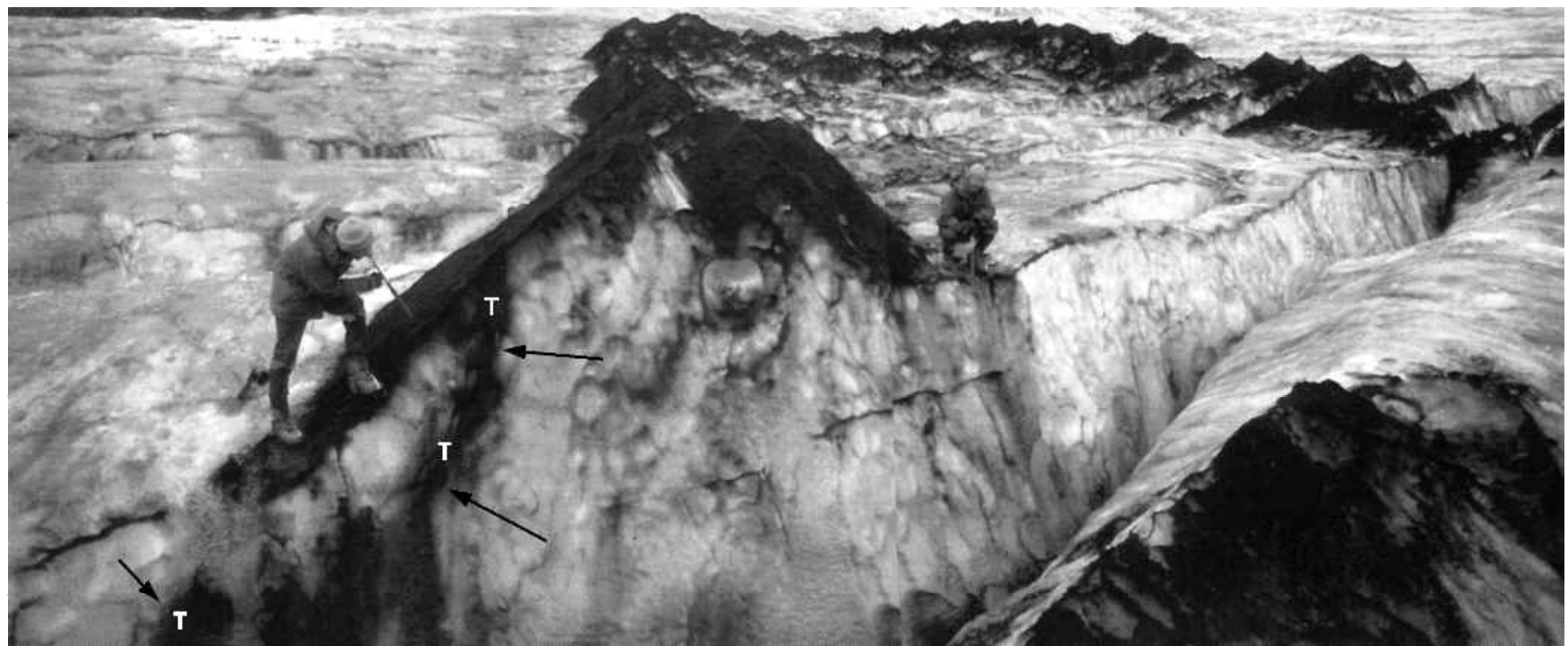

Fig. 5. Hekla 1947 tephra exposed in the ablation zone of Gigjökull. Upstream view of a large accordion fold picked out by ice-cored tephra ridge. Arrows and letters (T...T) show location of englacial septum. Slight darkening of glacier surface is due to the residual tephra cover.

the tephra to be let down onto underlying ice surfaces, ablation for a given thickness would reduce according to curve B (Fig. 2). At the low altitudes of the main glacier termini, curve B would have applied to ablation-season melt. By this time, some reworking of the cover would have occurred, leading to larger local variations in thickness but probably with little removal of tephra from the glaciers until ablation rates peaked in mid-summer. Tephra thickness and ablation differential increased towards the terminus of Gígjökull (Fig. 4), so maximum insulation occurred on that part of the glacier which normally experienced highest ablation rates. The ablation gradient was reversed within $1 \mathrm{~km}$ of the contemporary terminus.

The accumulation zone, by contrast, is calculated to have been subject to a modest increase in ablation (up to $\sim 8 \%$ from curve A) which would, in any case, only have extended until the next snowfall after the airfall event. The

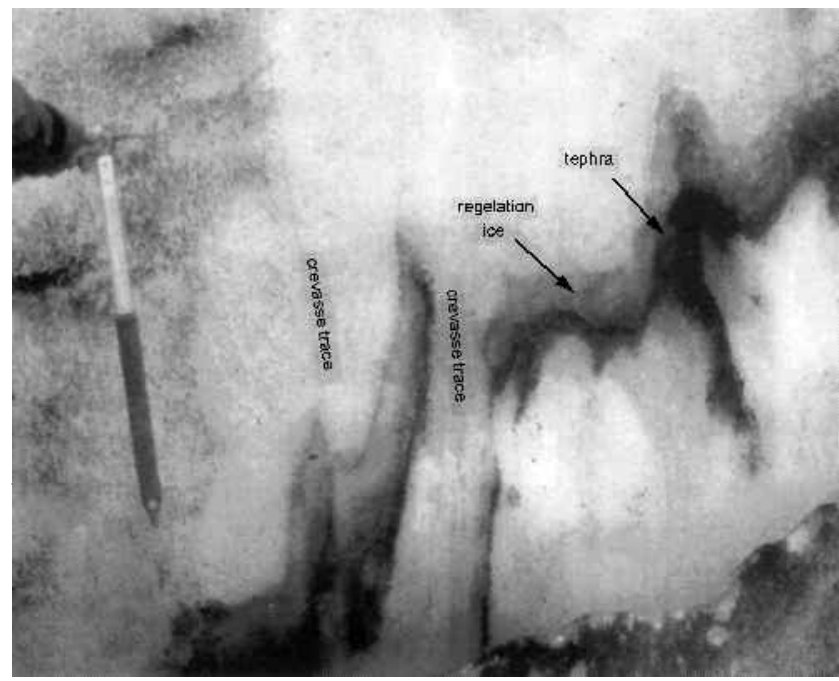

Fig. 6. Cleaned crevasse wall showing the contrast between bubbly white ice and band of darker regelation ice immediately above the englacial tephra septum. Discontinuities in the septum are offsets along crevasse traces. The ice axe is $70 \mathrm{~cm}$ long.
20-30 mm tephra layer entrained within the 1947 snowpack has, since the early 1980s, been ablating to the surface in the terminal area as a double syncline with tight, accordion-like folding of the limbs, following transport through two icefalls (Fig. 5). Exposure of the tephra layer in crevasse walls shows a difference in ice crystallography above and below the tephra (Fig. 6). Ice beneath the tephra represents the contemporary snow surface on 29 March 1947 and shows no evidence of regelation. By inference, the tephra had cooled to the ambient air temperature before deposition, and no melting occurred beneath the tephra before burial by snow. Ice immediately overlying the tephra probably represents the first autumn snowfall of 1947. This consists of a 60$100 \mathrm{~mm}$ thick layer of darker ice with lower bubble content, indicating partial melting and refreezing of the snowpack. The emerging tephra septum (englacial debris band) now provides supraglacial cover which reduces ablation only along the line of outcrop (Fig. 5), and as lines of ablation cones along supraglacial stream courses. Elsewhere, particles of the dacitic ash are now very dispersed on the ice below the outcrop, and represent the residual cover following stripping by runoff and wind. The thermal effect 50 years after the tephra fall is therefore minor, and restricted to very localized insulation and ablation cone formation, but with more widespread (though minor) darkening of the glacier surface.

No major glacier termini occur to the west of Gígjökull, where the ice-cap margin takes the form of a thin, tapering fringe at 700-1000 m a.s.l. The southern margin includes seven distinct lobes draining contiguous accumulation zones, all of which lay in the zone of accelerated ablation. The terminus of Seljavallajökull (Fig. 2) was covered by $\sim 17 \mathrm{~mm}$ of tephra with a corresponding calculated ablation differential of $+25 \%$, trending to $20 \mathrm{~mm}$ and $+8 \%$ at the ice divide. The regional pattern is therefore one of great contrast, even within a small ice cap only $15 \mathrm{~km}$ along the east-west axis. Straddling the eastern half of the fallout plume, where tephra thickness decreased sharply away from the downwind axis, Eyjafjallajökull experienced great variation in the calculated ablation differential, from $+85 \%$ in the east to an extrapolated value of $\sim-65 \%$ in the west. It 


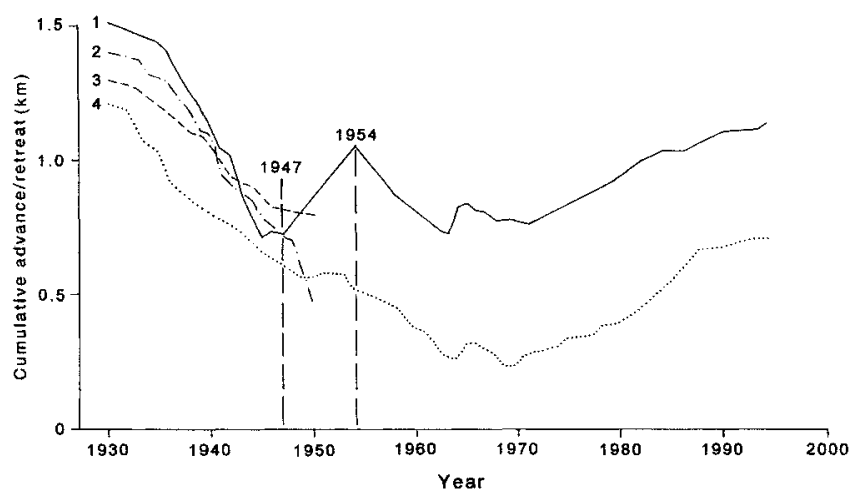

Fig. 7. Frontal changes of selected glaciers which received supraglacial airfall in the 1947 eruption (from Sigurdsson, 1998). 1 = Gígjökull; 2, 3 = Seljavallajökull; $4=$ Sólheima jökull.

follows that the immediate post-eruption responses of the glaciers draining the ice cap are expected to reflect the contrasts in their surface condition.

\section{PRE- AND POST-ERUPTION GLAGIER FLUGTUATIONS}

\section{Records of glacier fluctuations in south Iceland}

Compilation of records of the frontal changes of 61 glaciers (Sigurðsson, 1998) covers the period 1930-95, and reveals the general mass-balance trend of non-surging glaciers in Iceland, allowing anomalous behaviour to be identified. Fluctuations of three glaciers within the airfall zone of the 1947 eruption are recorded over the relevant period (Fig. 7): two on Eyjafjallajökull (Gígjökull and Seljavallajökull) and one on Mýrdalsjökull (Sólheimajökull). Both Seljavallajökull and Sólheimajökull have two termini, and records include fluctuations of each (Sigurðsson, 1998). However, the record of terminus change at Gígjökull contains significant gaps. It was measured annually from 1934 to 1947, then not until 1954, followed by another gap until 1963, and more frequently thereafter. Sigurðsson (1998) has synthesized these data with aerial photographic measurements from 1946, 1960 and 1980, and with Eypórsson's (1963) information on the total change between 1943 and 1954. The time--distance diagram in Figure 7 is the best interpretation of these data.

\section{Fluctuations of Gígjökull since 1930 compared to other glaciers}

The regional trend is one of slow retreats in the early 1930s, accelerating through the second half of the decade and into the early 1940s. Thereafter retreats continued at slower rates through to the 1970 s, punctuated by minor readvances in the late 1940s and early 1960s. From 1970 onwards, cooler summers caused many glacier termini to stabilize or advance (Jóhannesson and Sigurðsson, 1998; Kirkbride, 2002). Gígjökull experienced particularly rapid retreat of $\sim 700 \mathrm{~m}$ between 1935 and 1945, though the general trend matched other termini monitored at Eyjafjallajökull and Mýrdalsjökull (Fig. 7). The retreat appeared to have ended abruptly in 1945 , followed by a $14 \mathrm{~m}$ advance in $1945 / 46$ and a $10 \mathrm{~m}$ retreat in 1946/47. The absence of observational data between $1947 / 48$ and 1954/55 means that the exact timing of the onset of the next advance is not documented. By 1954, however, the terminus was $328 \mathrm{~m}$ beyond its 1946 position and deposited an ice-cored terminal moraine visible on 1960 aerial photographs. The magnitude of the advance is such that the onset must have occurred several years prior to 1954. Following a similar distance and rate of retreat, a further short-lived advance in 1963-65 was followed by several years of slow retreat, then sustained advance until the late 1990s. By 1988, the glacier had over-ridden the 1954 terminus position.

Prior to 1947, and after 1954, fluctuations of Gígjökull closely follow the regional pattern. Between 1930 and 1945, fluctuations of Gígjökull and the main (western) terminus of Sólheimajökull differed only in their rate of retreat. The post-eruption advance of Gígjökull overlaps with a very small and short-lived advance of Sólheimajökull between 1948/49 and 1950. By 1951 this glacier was once again in retreat. Gígjökull continued to advance until sometime before 1954 , after which a comparably rapid retreat lasted until 1963. A small readvance occurred in 1963-65 at both glaciers, and their subsequent fluctuations correlate closely. At Seljavallajökull, the 1947-50 period was one of accelerated retreat (a change from $\sim-48 \mathrm{ma}^{-1}$ in $1944-47$ to $\sim 80 \mathrm{~m} \mathrm{a}^{-1}$ from 1947 to the end of observations in 1950). This rate of recession exceeds any other in the records for Eyjafjallajökull and Mýrdalsjökull outlet glaciers.

By comparison with these and other records for glaciers throughout Iceland, the $\sim 1947-54$ advance is anomalous in both its magnitude and duration, to a degree that cannot be attributed to gaps in the series of observations. The immediate post-eruption coincidence of greatly reduced melting in the ablation zone of Gígjökull (Fig. 3) with an immediate and unique reversal of the mass-balance trend (Fig. 7) leads to the conclusion that a causal relationship existed. Furthermore, it is tempting to suggest that the accelerated retreat of part of Seljavallajökull may also have had a volcanogenic origin due to increased melt under a thin tephra cover on a relatively steep south-facing slope. Fluctuations of other glaciers do, however, indicate a very minor advance in the late 1940s. Fluctuations of Gígjökull and Sólheimajökull are similar enough to imply that a comparably small advance of Gígjökull would probably have occurred without the tephra fall. Nevertheless, the inferred earlier date of inception of Gígjökull's advance, together with its magnitude and duration, suggest that the major cause was retarded ablation beneath the 1947 tephra cover.

\section{DISGUSSION}

Comparison of the H1947 isopach map with the time series of glacier terminus change indicates that an advance of Gígjökull was triggered by reduced ablation beneath the supraglacial cover. The timing, rate and duration of advance provide clues for identifying other volcanically triggered advances, both from records of frontal change and within dated moraine sequences.

\section{Relationships between fallout and glacier response}

One characteristic of the 1947-54 advance was its instantaneous onset, commensurate with an immediate and glacierscale reduction in ablation rate. As soon as ablation was reduced, continued ice flow caused the terminus to advance. The timing of the eruption in late March would have reduced the normal summer melt-back of the terminus, particularly because the tephra fell onto a stable snow pack before ablation 

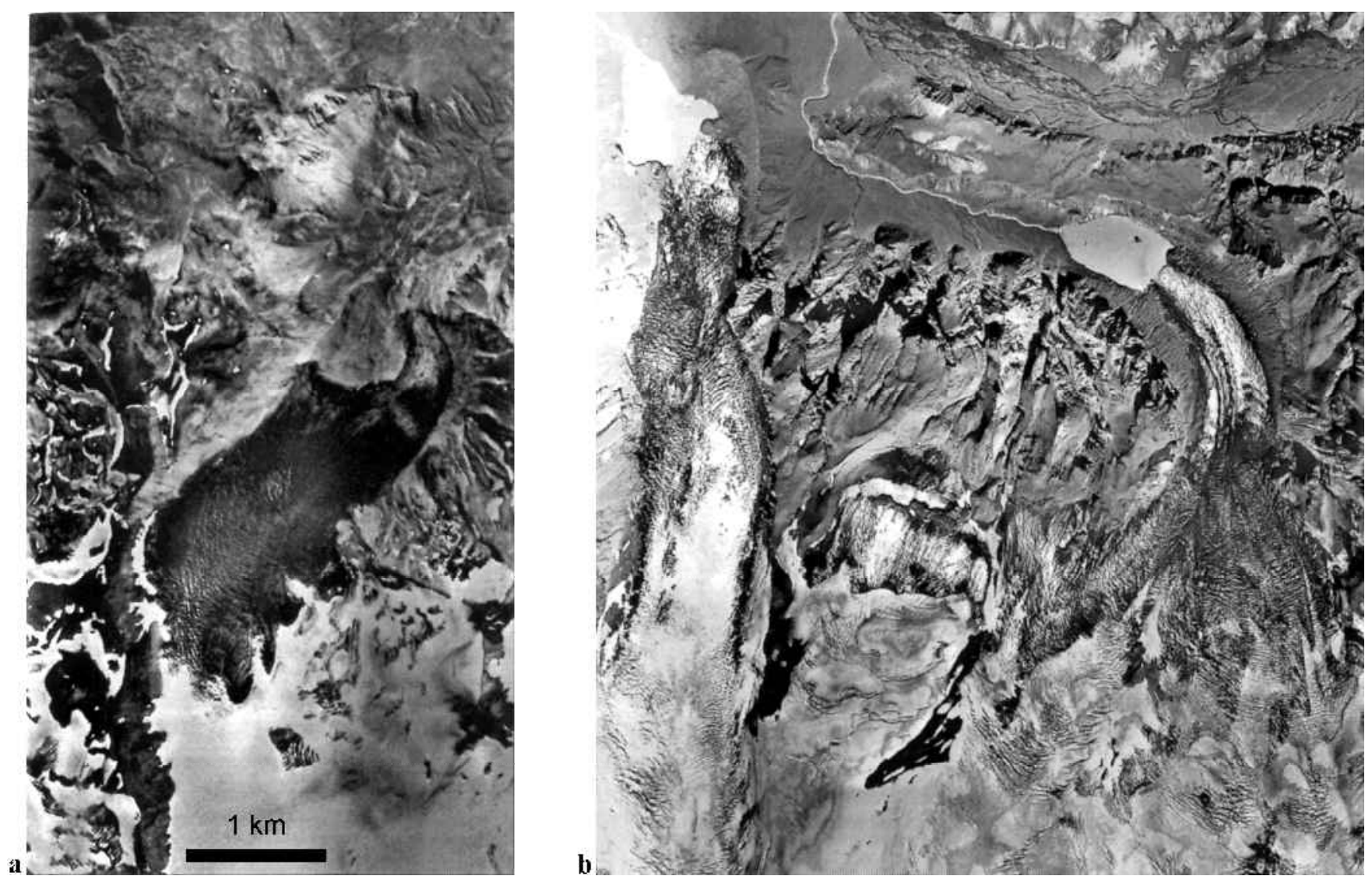

Fig. 8.1960 vertical aerial photographs, at the same approximate scale, of (a) Tindfjallajökull (north to left) and (b) Gígjökull and Steinsholtsjökull (north to top). H1947 tephra is present as a thick, black supraglacial cover with snow-filled crevasses and rills on Tindfjallajökull, and as a thin, dispersed but widespread cover on Gigjökull, Steinsholtsjökull and below the nearby firn limits. (Reproduced with the permission of Landmalingar Islands.)

rates increased in early summer, rather than onto a melting ice surface. A general implication is that the initial rate of advance will be most pronounced at glaciers where, for a given reduction in ablation rate, terminus velocities are greater. The occurrence of post-fallout advances will therefore be preconditioned by the presence or absence of glaciers able to respond to the reduced ablation, as well as to the thickness and insulation of the tephra cover.

The duration of advance will have been limited by the rapid reworking of new-fallen tephra in Iceland (Hunt, 1994). Supraglacial tephra is much more easily eroded from glacier surfaces than rockfall-fed covers. Glaciers bearing thick rockfall mantles become extended until their ablation areas are large enough to offset the reduction in specific ablation rates beneath the debris cover, so that accumulation-area ratios are lower than for uncovered glaciers. While advances triggered by tephra falls represent a similar response, the cover is rapidly stripped with no ongoing resupply (because eruptions are infrequent relative to the time taken to erode the supraglacial tephra), so the extension of the ablation zone is a transient response and not a characteristic state (cf. Kirkbride, 2000). The duration of advance is determined by the time taken to reduce the tephra cover to the point where ablation at the terminus is accelerated (the critical thickness is crossed). Removal of the cover is patchy, but aerial photographs from the decades after the H1947 event (Fig. 8) show an altitudinal sequence of removal in which bare ice is re-exposed first at the terminus and later at higher altitudes. This pattern reflects shorter subaerial exposure due to protection by seasonal snow cover and lower runoff from ice surfaces at higher elevations. Removal of the cover can therefore be envisaged as upstream migration of the critical and effective thickness lines. If renewed retreat is caused by increased ablation, the time taken for an insulating cover to be removed is indicated by the duration of the advance ( $\leq 7$ years on the low-gradient tongue of Gígjökull). This is consistent with observations from 1960 aerial photographs, which show bare ice at the terminus of Gígjökull and patchy cover in the lower icefall (Fig. 8). Advances of this type are therefore short-lived, at least at the low altitude $(170 \mathrm{~m})$ of the terminus. If post-eruption mass balances are positive for only a few years, the earlier conclusion that fastflowing glaciers will preferentially record the event as an advance is reinforced. After removal, dispersed and patchy tephra cover survives where particles are trapped in cryoconites, along crystal boundaries, and held in surface tension on the wet ice surface. Darkening of the surface appears almost permanent, increasing albedo and ablation above the "clean"-ice rate.

\section{Can the mass-balance effect of the tephra cover explain the anomalous advance?}

A deductive approach is taken to quantifying the volumetric magnitude of the advance in comparison to the mass-balance change due to insulation by the tephra layer. Calculations include, first, the change in glacier volume associated with a $328 \mathrm{~m}$ advance; second, the volume loss of ice from the lower glacier under "clean-ice" conditions. These then allow an estimate to be made of the mean 7 year ablation rate necessary to 
allow the observed advance to happen. This mean rate should be much less than the maximum reduction in ablation under the newly deposited tephra layer, due to removal of the tephra from the glacier over the 7 year period. The estimate of the effect on mass balance of newly deposited tephra relates to the immediate post-eruption period, whereas the volume gain occurred over seven subsequent years.

These estimates necessarily rest on several assumptions: (1) that the 1947-54 advance involved the formation of a low-gradient tongue extending beyond steeper ice below the lower icefall. The glacier advanced from a bedrock substrate onto the sedimentary bed of a lake basin, implying a reduction in basal shear stress and lowering of surface gradient. The expanded glacier in recent decades has also taken this form; (2) that, due to velocity constraints, only ice gained in the lower part of the glacier contributed to the advance. Estimates were made for the lower 1 and $2 \mathrm{~km}$ of the pre-advance glacier; (3) that curve B in Figure 2 applies, because for most of the advance period the tephra would be lying on an ice substrate.

For a linear advance of $328 \mathrm{~m}$ to have occurred, the net mass gain over 7 years is estimated to be $\sim 11.1 \times 10^{6} \mathrm{~m}^{3}$, based on a wedge-shaped terminus $500 \mathrm{~m}$ wide with a gradient of 0.144 . The 7 year ablation under "clean-ice" conditions of the pre-eruption terminus would have been $\sim 29.8 \times 10^{6} \mathrm{~m}^{3}$, based on a mean ablation of $8.5 \mathrm{~m} \mathrm{a}^{-1}$ over the lower $1 \mathrm{~km}$ of the pre-eruption glacier (from Fig. 4). The net mass gain represents $37 \%$ of this 7 year ablation under "clean-ice" conditions, which is the proportionate reduction in ablation which would have been necessary to bring about the advance. If the lower $2 \mathrm{~km}$ of the glacier are considered, the "clean-ice" ablation becomes $36.8 \times 10^{6} \mathrm{~m}^{3} \mathrm{a}^{-1}$ at a mean ablation rate of $5.25 \mathrm{~m} \mathrm{a}^{-1}$, corresponding to a $30 \%$ reduction in ablation. Immediate post-eruption ablation was reduced by up to $80 \%$ on the lower glacier (Fig. 3). The mean 7 year estimate of $\sim 30-37 \%$ reduction in ablation seems consistent with the magnitude of the advance and an eroding tephra cover providing less insulation over time.

\section{Volcanogenic advances in the glacio-geomorpho- logical record?}

The glaciological effects of the 1947 eruption raise the question of whether evidence of volcanically triggered advances occurs within the record of Little Ice Age (LIA) moraines, complicating palaeoclimatic interpretations. The glacial chronology of south Iceland consists of $\sim 70$ years of direct measurement of terminus positions (Sigurðsson, 1998), and reconstructions based on landform evidence for the later part of the LIA (AD 1700-1900). Multiple advances and many recessional moraines have been dated by tephrochronology, historical records and lichenometry (Gudmundsson, 1997, 1998; Evans and others, 1999; Kirkbride and Dugmore, 2001a). An association between volcanism and glacier fluctuations has been suggested by Evans and others (1999) for Sandfellsjökull and Öldufellsjökull (Fig. 1). They interpret lichenometrically dated moraines as a result of readvances caused by tephra cover from the 1918 eruption of Katla, $10-15 \mathrm{~km}$ to the southwest. The timing and duration (5-7 years) of these advances is consistent with our results from Gígjökull.

However, dating precision is not likely to be better than a decade using proxy techniques, yet to distinguish definitively a volcanic trigger from a short-term climatic trigger requires recognition of an immediate response. Even a lag of 1 year between an airfall event and a glacier response is enough to rule out the airfall as the primary forcing mechanism (though any change in surface condition will modify the climatic response). Hence, it will not usually be possible to identify individual moraines as anomalous relative to a regional climatic control set, in the way that observed glacier fluctuations have been used in this paper. Advances triggered by earlier LIA eruptions (e.g. Hekla in 1766; Katla in 1625, 1660, 1721, 1755, 1823 and 1860; Öraefajökull in 1727) will be very difficult to distinguish, particularly in the light of reservations about the time range of lichenometric dating (Bradwell, 2001; Kirkbride and Dugmore, 2001a). In prehistory, Katla tephra layers L (2260 \pm 60 years BP) and K (3480 \pm 60 years BP) distributed thick tephra south of Mýdalsjökull and would have greatly affected contemporary glaciers on the south coast of Iceland. Although Sólheimajökull retreats from a Neoglacial highstand after the deposition of layer K (Dugmore, 1989), it is not possible to resolve dating sufficiently to show if the two events are connected.

The Grimsvötn caldera also reached peaks of activity of 6-11 small eruptions per 40 years between 1720 and 1880 (Larsen and others, 1998), but these tephras fell largely within the accumulation zone and would have been rapidly buried by snowfall and largely remain in englacial transport. Older tephras, such as those dating between 1783 and 1222 , now outcrop in the ablation zone of the larger outlet glaciers of Vatnajökull (Larsen and others, 1998) to maintain a semi-permanent reduction in ice surface albedo rather than provide episodic triggers for advances. As a result, times of increased tephra production generally promote more negative glacier mass balance.

Much greater impacts will have been associated with eruptions an order of magnitude larger than those of the last 300 years; some of these produce dark-coloured tephra similar to the examples discussed so far, but others, notably the major silicic eruptions of Hekla, produce white or lightcoloured tephra. Although this would produce a modified critical thickness threshold, the effective thickness is likely to have been similar. The silicic H1104 eruption and prehistoric silicic eruptions H3 ( 2900 years BP) and H4 $(\sim 3834 \pm 15$ years BP $)$ dispersed major tephra deposits to the north (Larsen and Thórarinsson, 1977; Dugmore and others, 1995). Isopachs for H3 and H4 fallout show thicknesses exceeding $100 \mathrm{~mm}$ over eastern Langjökull and Hofsjökull (Larsen and Thórarinsson, 1977). Where pre-LIA moraines of small glaciers have been dated within the $\mathrm{H} 3$ and H4 fallout zones (Stötter, 1991; Kirkbride and Dugmore, 2001b) they are bracketed by these tephra and have no temporal association with the $\mathrm{H} 3$ and $\mathrm{H} 4$ eruptions. If indeed glaciers did advance at these times, their moraines have either been over-ridden or remain to be identified. In early-Holocene and Late-glacial times, major darkcoloured basaltic tephras such as Saksunarvatn, Vedde and the other components of North Atlantic Ash Zone One will have also covered extensive areas of the Icelandic ice sheet at crucial times and will also have modified glacier mass balance. The challenge of identifying any resulting geomorphological record will be great given the generally lowerresolution landform record of that time.

\section{A model of glacier response within zones of airfall deposition}

The variety of glacier responses to distal tephra fall is sche- 


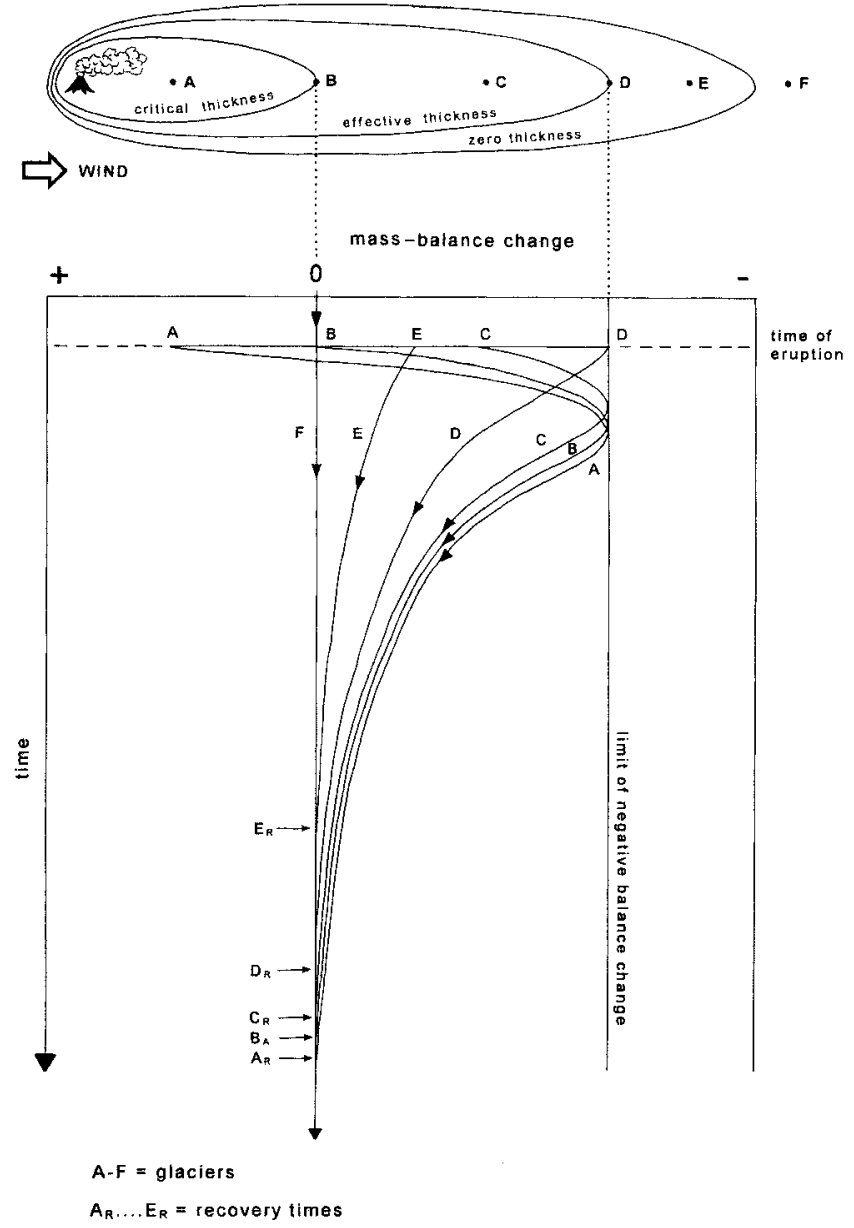

Fig. 9. Space-time model of the pattern of mass-balance variation of glaciers within the airfall zone. All glaciers are assumed to differ only in their location and all have equilibrium mass balance at the outset. See text for explanation.

matized in Figure 9. Primary tephra thickness decreases exponentially away from the eruptive source (Sparks and others, 1997), and for simplicity only a single critical and effective thickness applies. Five glaciers, labelled A-E, lie on the downwind axis of the tephra plume. It is assumed that the response depends solely on tephra thickness, so the curves representing the post-eruption mass-balance perturbation are essentially the same for all glaciers. They differ only in that glacier responses have different starting points on this curve according to the primary thickness of supraglacial tephra. Glaciers in more distal locations follow more truncated response paths and regain equilibrium sooner than glaciers in proximal locations where removal of thicker covers takes longer.

Glacier A lies upwind of the critical thickness line, and ablation is initially reduced to give positive mass balance. Post-depositional thinning of the tephra cover increases ablation above the immediate post-eruption rate until ablation becomes increased relative to bare ice. A prolonged phase ensues in which balance becomes more negative as tephra cover thins to the effective thickness. Subsequent thinning will lead to a return to lower ablation rates, but always above the clean-ice rate until the cover has been completely removed. Once the cover is thin and patchy, total removal takes many decades, in which time negative balance will prevail. Convergence with the equilibrium mass-balance line becomes more acute over time, because removal of each increment of tephra mass becomes more difficult as the cover becomes thin and dispersed.

Glaciers B-E all follow the same mass-balance pathway, but have different starting points because they have different initial thicknesses of tephra cover. Glacier B lies on the critical thickness line, so stripping of the cover takes the glacier through a complete negative-balance cycle but without a preceding positive-balance phase. Glacier $\mathrm{C}$ lies between the critical and effective thickness lines, so ablation will initially increase then decrease as cover is reworked. Glacier D lies on the effective thickness line immediately following fallout and so experiences only a decreasing trend in ablation. Glacier E shows the most truncated pathway and the earliest return to equilibrium balance conditions, lying close to the limit of airfall deposition. Applied to the 1947 eruption, path A would represent Gígjökull, path C Seljavallajökull, and path $\mathrm{E}$ the western outlets of Mýdalsjökull close to the airfall limit.

In nature, glaciers would follow a variety of forms of mass-balance curve because of their differing areas, slopes, velocities, altitudes and prior mass-balance states. Regional response will appear complex, with some glaciers seeming not to respond at all while others show disproportionately large responses. The differences will lie not just in the variation of initial tephra cover, but in the differing sensitivities of response of glaciers to the ablation trigger. The long-term effect of tephra falls on mass balance will probably be a negative one. Historical eruptions, predominantly forming lowsilicic, dark tephras, have produced fallout zones in which tephra thicknesses below the critical thickness for ablation greatly exceed the area of above-critical thickness. This paper indicates that glacier advances, where they do occur, will be localized and short-lived, and will punctuate prolonged periods when ablation zones are darkened by the thin and dispersed remnants of tephra covers typified by many ablation zones in south Iceland at the present time.

\section{GONGLUSIONS}

Direct observations of terminus position and tephra thickness indicate that the H1947 eruption caused an advance of Gígjökull in response to reduced ablation under the supraglacial tephra cover. The magnitude ( $328 \mathrm{~m}$ ) and duration (7 years) of the advance were sufficient to leave a geomorphic signature in the landscape, demonstrating a cause-and-effect relationship between even modest airfalls and localized glacier advance. Regionally, the occurrence of significant advances requires both thick supraglacial covers and fast ice velocities at the terminus to allow the increased mass balance to be manifest as an advance within the few years available before ablation is increased as the cover is stripped back. The three glaciers where volcanically induced triggers have been identified (Gígjökull, Sandfellsjökull and Öldufellsjökull) are all relatively fast-flowing outlet glaciers. Similar volcanogenic advances must have occurred during the Neoglacial and LIA, but their identification in the pre-20th-century landform record is problematic because of poor moraine preservation and dating. The long-term effect of volcanic fallout in Iceland is to reduce albedo under a very thin, patchy residual cover, which will have a negative influence on glacier mass balances over periods of decades. 


\section{ACKNOWLEDGEMENTS}

The authors would like to thank several people for their constructive comments at several stages of this paper: in particular, O. Sigurðsson (National Energy Authority, Reykjavík) and the referees M. T. Guðmundsson and N. Reeh. The Scientific Editor was G. S. Hvidberg. Data on ablation rates under tephra at Gígjökull were collected over several years by geography students at the University of Edinburgh. The support of the Carnegie Trust for the Universities of Scotland and the Leverhulme Trust for research in Iceland is gratefully acknowledged.

\section{REFERENCES}

Adhikary, S., K. Seko, M. Nakawo, Y. Ageta and N. Miyazaki. 1997. Effect of surface dust on snow melt. Bull. Glacier Res. 15, 85-92.

Adhikary, S., M. Nakawo, K. Seko and B. Shakya. 2000. Dust influence on the melting process of glacier ice: experimental results from Lirung Glacier, Nepal Himalayas. International Association of Hydrological Sciences Publication 264 (Symposium at Seattle 2000-Debris-Covered Glaciers), 43-52.

Ahlmann, H.W. and S. Thórarinsson. 1938. The ablation. Geogr. Ann., 20(3-4), 171-233.

Bozhinskiy, A. N., M. S. Krass and V. V. Popovnin. 1986. Role of debris cover in the thermal physics of glaciers. F. Glaciol., 32(111), 255-266.

Bradwell, T. 2001. A new lichenometric dating curve for southeast Iceland. Geogr. Ann., 83A(3), 91-101.

Branney, M. J. and J. S. Gilbert. 1995. Ice-melt collapse pits and associated features in the 1991 lahar deposits of Volcan-Hudson, Chile: criteria to distinguish eruption-induced glacier melt. Bull.Volcanol., 57(5), 293-302.

Brugman, M. M. and M. F. Meier. 1981. Response of glaciers to eruptions of Mount St. Helens. U.S. Geol. Surv. Prof. Pap. 1250, 743-756.

Clark, S. P., Jr. 1966. Section 21. Thermal conductivity. In Clark, S. P., Jr, ed. Handbook of physical constants. Boulder, CO, Geological Society of America, 459-482. (GSA Memoir 97.)

Driedger, C. L. 1981. Effect of ash thickness on snow ablation. U.S. Geol. Surv. Prof. Pap. 1250, 757-760.

Dugmore, A. J. 1989. Tephrochronological studies of Holocene glacier fluctuations in south Iceland. Glacier fluctuations and climatic change. In Oerlemans, J., ed. Glacier fluctuations and climatic change. Dordrecht, etc., Kluwer Academic Publishers, 37-55.

Dugmore, A. J., J. S. Shore, G. T. Cook, A. J. Newton, K. J. Edwards and G. Larsen. 1995. The radiocarbon dating of tephra layers in Britain and Iceland. Radiocarbon, 37, 286-295.

Evans, D. J. A., S. Archer and D. J.H. Wilson. 1999. A comparison of the lichenometric and Schmidt hammer dating techniques based on data from the proglacial area of some Icelandic glaciers. Quat. Sci. Rev., 18(1), 13-41.

Eypórsson, J. 1963. Variations of Icelandic glaciers 1931-1960. Fökull, 13, 31-33.

Fujii, Y. 1977. Field experiment on glacier ablation under a layer of debris cover. Seppyo, Special Issue 39, 20-21.

Gudmundsson, H. J. 1997. A review of the Holocene environmental history of Iceland. Quat. Sci. Rev., 16(1), 81-92.

Gudmundsson, H.J. 1998. Holocene glacier fluctuations and tephrochronology of the Öræfi district, Iceland. (Ph.D. thesis, University of Edinburgh.)

Humlum, O. 1996. Origin of rock glaciers: observations from Mellemfjord, Disko Island, central west Greenland. Permafrost and Periglacial Processes, 7(4), 361-380.

Hunt, J. B. 1994. The mobility and redeposition of the Hekla 1991 tephra, and the effects of wind and snow. Münch. Geogr. Abh., Ser. B, 12, 157-175.

Jóhannesson, T. and O. Sigurðsson. 1998. Interpretation of glacier variations in Iceland 1930-1995. Fökull, 45, 27-33.

Kayastha, R. B., Y. Takeuchi, M. Nakawo and Y. Ageta. 2000. Practical prediction of ice melting beneath various thickness of debris cover on Khumbu Glacier, Nepal using a positive degree-day factor. International Association of Hydrological Sciences Publication 264 (Symposium at Seattle 2000-Debris-Covered Glaciers), 71-81.

Khan, M. I. 1989. Ablation on Barpu Glacier, Karakoram Himalaya, Pakistan: a study of melt processes on a faceted, debris-covered ice surface. (M.Sc. thesis, Department of Geography, Wilfrid Laurier University, Waterloo, Ontario.)

Kirkbride, M. P. 2000. Ice-marginal geomorphology and Holocene expansion of debris-covered Tasman Glacier, New Zealand. International Association of Hydrological Sciences Publication 264 (Symposium at Seattle 2000-DebrisCovered Glaciers), 211-217.

Kirkbride, M. P. 2002. Icelandic climate and glacier fluctuations through the termination of the "Little Ice Age". Polar Geogr., 26(2), 116-133.

Kirkbride, M. P. and A. J. Dugmore. 200la. Can lichenometry be used to date the "Little Ice Age" glacial maximum in Iceland? Climatic Change, 48(1), 151-167.

Kirkbride, M. P. and A. J. Dugmore. 2001b. The timing and significance of mid-Holocene glacier advances in northern and central Iceland. 7 . Quat.Sci., 16(2), 145-153.

Kirkbride, M. P. and C. R. Warren. 1999. Tasman Glacier, New Zealand: 20th-century thinning and predicted calving retreat. Global Planet. Change, 22(1-4), 11-28.

Konovalov, V. 2000. Computations of melting under moraine as a part of a regional modelling of glacier runoff. International Association of Hydrological Sciences Publication 264 (Symposium at Seattle 2000-Debris-Covered Glaciers), 109-118.

Larsen, G. and S. Thórarinsson. 1977. H4 and other acidic Hekla tephra layers. Fökull, 27, 28-46.

Larsen, G., M. T. Gudmundsson and H. Björnsson. 1998. Eight centuries of periodic volcanism at the center of the Iceland hot spot revealed by glacier tephrastratigraphy. Geology, 26(10), 943-946.

Lister, H. 1953. Report on glaciology at Breiðamerkurjökull 1951. Jökull, 3 $23-31$

Loomis, S. R. 1970. Morphology and ablation processes on glacier ice. In Bushnell, V. C. and R. H. Ragle, eds. Icefield Ranges Research Project; Scientific Results. Vol. 2. Montréal, Que., Arctic Institute of North America; New York, American Geographical Society, 27-31.

Lundstrom, S. C., A. E. McCafferty and J. A. Coe. 1993. Photogrammetric analysis of 1984-89 surface altitude change of the partially debris-covered Eliot Glacier, Mount Hood, Oregon, U.S.A. Ann. Glaciol., 17, 167-170.

Major, J. J. and G. G. Newhall. 1989. Snow and ice perturbation during historical volcanic eruptions and the formation of lahars and floods. A global review. Bull. Volcanologique, 52, 1-27.

Mattson, L. E. and J. S. Gardner. 1991. Energy exchanges and ablation rates on the debris covered Rakhiot Glacier, Pakistan. Z. Gletscherkd. Glazialgeol., 25(1), 1989, 17-32.

Østrem, G. 1964. Ice-cored moraines in Scandinavia. Geogr. Ann., 46(3), 282-337

Pierson, T. C., R. J. Janda, J.-C. Thouret and C. A. Borrero. 1990. Perturbation and melting of snow and ice by the 13 November 1985 eruption of Nevado del Ruiz, Colombia, and subsequent mobilization, flow, and deposition of lahars. F. Volcanol. Geotherm. Res., 41(1-4), 17-66.

Salmi, M. 1948. The Hekla ashfalls in Finland, AD 1947. Suomen Geol. Seura, 21, 87-96.

Sigurðsson, O. 1998. Glacier variations in Iceland 1930-1995: from the database of the Iceland Glaciological Society. Fökull, 45, 3-25.

Small, R. J. and M. J. Clark. 1974. The medial moraines of the lower Glacier de Tsidjiore Nouve, Valais, Switzerland. 7. Glaciol., 13(68), 255-263.

Sparks, R. S. J. and 6 others. 1997. Volcanic plumes. Chichester, etc., Wiley.

Stötter, J. 1991. New observations on the postglacial glacial history of Tröllaskagi, northern Iceland. In Maizels, J. K. and C. Caseldine, eds. Environmental change in Iceland: past and present. Dordrecht, etc., Kluwer Academic Publishers, 181-192. (Glaciology and Quaternary Geology 7.)

Sturm, M., C. Benson and P. MacKeith. 1986. Effects of the 1966-68 eruptions of Mount Redoubt on the flow of Drift Glacier, Alaska, U.S.A. F. Glaciol., 32(112), 355-362.

Syverson, K. M. and D. Mickelson. 1995. Ablation of debris-covered ice and the formation of pitted outwash plains at Burroughs Glacier, southeastern Alaska. In Engstrom, D. R., ed. Proceedings of the Third Glacier Bay Science Symposium, 1993. Anchorage, AK, U.S. Department of the Interior. National Park Service, 66-74

Thórarinsson, S. 1950. The approach and beginning of the Hekla eruption: eyewitness accounts. In Einarsson, T., G. Kjartansson and S. Thórarinsson, eds. The eruption of Hekla 1947-48. Vol. II (1). Reykjavík, Vísindafélag Íslendinga Societas Scientarum Islandica.

Thórarinsson, S. 1954. The tephra fall from Hekla on March 29 1947. In Einarsson, T., G. Kjartansson and S. Thórarinsson, eds. The eruption of Hekla 1947-48. Vol. II (3). Reykjavík, Vísindafélag Íslendinga Societas Scientarum Islandica.

Thouret, J. C. 1990. Effects of the November 131985 eruption on the snowpack and ice cap of Nevado del Ruiz volcano, Colombia. 7. Volcanol. Geotherm. Res., 41(1-4), 177-201.

Trabant, D. C. and D. F. Meyer. 1992. Flood generation and destruction of "Drift" Glacier by the 1989-90 eruption of Redoubt Volcano, Alaska. Ann. Glaciol., 16, 33-38. 